\title{
EFFECTIVENESS OF THE SANDPITS SECURITY SYSTEM AGAINST MICROORGANISMS AND INTESTINAL PARASITES SAND CONTAMINATION
}

\author{
Magdalena Błaszak' ${ }^{1}$ Kinga Zatoń
}

1 Department of Microbiology and Environmental Biotechnology, Faculty of Environmental Management and Agriculture, West Pomeranian University of Technology in Szczecin, Słowackiego 17 Str., 71-434 Szczecin, Poland, e-mail: mablaszak@zut.edu.pl

Received: 2015.07.13

Accepted: 2015.08.31

Published: 2015.10.01

\begin{abstract}
Playgrounds and sandpits (small architecture objects according to the Construction Law) are subject to meticulous supervision, both at the design stage and subsequent status checks of the objects. One of the requirements arising from the need to protect playgrounds from animals is the necessity for fencing the object (Regulation of 31 December 2002 On Safety and Hygiene in Public and Private Schools and Institutions; Polish Standard PN-EN 1176 Playground equipment and surfacing). Does fencing playgrounds really reduce contamination of sand? To verify this hypothesis, the studies have been conducted on the residential areas' sandpits, both fence secured and unsecured, located in close proximity to one another. The aim of the study was to evaluate the effectiveness of fences and nets as protection from microbial and parasite contamination of sandpits, mainly due to the access of animals to them. For several seasons of spring and summer the sand was examined in terms of the total number of heterotrophic bacteria and fungi (organic matter contamination of sand indicators) and for the presence of coliform bacteria (including Escherichia coli), bacteria of the Salmonella genus and the eggs of intestinal parasites. It can be concluded that fencing playgrounds affects sand pollution less with waste and plant material (as a consequence, it has been reported statistically significantly less heterotrophic bacteria and fungi in the fenced sandpits' sand). Unfortunately, the fence does not eliminate the risks associated with sand pollution of coliform bacteria. Cats and birds, but also dogs, still have a continuous access to sand. Due to the repeatedly stated carelessness of children and their caregivers, gates left open to the playground do not constitute an obstacle for domestic and stray animals. Another source of sand pollution with intestinal pathogens can be a manner of carriage of new sand, as there is no legislation governing the issue of transport. It has been visually found that the sand has been transported in a vehicle used for waste disposal.
\end{abstract}

Keywords: sandpits, children's sanitary safety, bacteria, fungi.

\section{INTRODUCTION}

Playgrounds are places in the public space requiring special engagement. Children playing there are not aware of many risks and dangers. The major dangers for children on the playground are accidents and injuries or pathogen infections while playing in the sandpit [Yearley and Berliński 2008; Ubowska and Łukaszewicz 2013]. Small children are not able to control the reflex of placing hands in their mouth, so the only thing that can be done to improve their safety is to ensure the quality of the sand. Pathogenic microorganisms and intestinal parasites are brought into the playgrounds' sand through the faeces of animals, mainly dogs and cats, less often birds or humans. Serious illnesses resulting from contact with contaminated sand are usually caused by bacteria of the Salmonella genus that cause salmonellosis. Dermatophytic fungus or yeast cause skin and nail fungal infection. Intestinal parasites Toxocara canis, T. cati cause serious toxocariasis; protozoan Toxoplasma gondii - cause toxoplasmosis [Borecka 2005; Kunicki-Goldfinger 
2005; Gawor et al. 2008; Duszczyk et al. 2012]. Surrounding playgrounds with fences is aimed at eliminating presence of animals on these objects and creating a safe zone area, free from rubbish and leaves blown in by the wind. The Laws oblige hosts and managers of real estates to build / upgrade playgrounds in terms of safety requirements [Dz. U. 2003 No 6 item 69; Dz. U. 2003 No 229 item 2275; Dz. U. 2008 No 234 item 1570; Dz. U. 2010 No 243 item 1623; Dz. U. 2011 No 83 item 454; PN-EN 1176].

Legal regulations strictly impose on playgrounds managers to establish a plan of annual periodic inspections as well as the maintenance of equipment and surfaces. It is recommended to regularly provide new sand (at least once a year), to isolate it from animals by fences and sandpit covers and to replace or repair damaged or expired recreational facilities. And all of these generate high costs for housing managers and directors of educational institutions. In some cities the sandboxes in some housing estates and kindergartens are routinely dismantled, as a response to changing security requirements and consequently increase of the cost of maintaining playgrounds [Berliński 2009; Pisera 2011; Warchala 2010; Lorenczewska 2015]. At the same time, also in recent years, we can see the growing number of modern sports fields and playgrounds being built on the areas adjacent to schools (mainly due to government and the local government program called Orlik, under the slogan Healthy and smiling children - most important!) as well as the modernization of the existing ones (but in those facilities there is rarely a sandpit built) [Gołdys et al. 2012]. Eliminating sandpits from playgrounds is an alarming trend since the designed and modeled sand constructions can provide perfect creativity and productivity exercises for children developing their sense of touch. Due to the best interest of the child, it is important to provide both the opportunity to play in the sandboxes, as this promotes the development of manual and creative skills, and the protection against pathogens [Ubowska and Łukaszewicz 2013].

The question arises whether the generated costs of adapting playgrounds (sandpits) to the requirements of the legislations are justified through the actual improvement of sanitary safety of the sand? Is the system of the medical care of children playing in the sandpits really settled? Comparing the sand (in terms of the content of microorganisms and parasites), taken from both secured and unsecured sandpits, the effectiveness of the security system currently required has been assessed.

\section{MATERIAL AND METHODS}

The used sand was collected in 2012 and 2013 from some Szczecin sandpits on the "Osiedle Książąt Pomorskich" estate and sandpits located on the "Górczyn" estate in Gorzów Wielkopolski. Testted material was important from sandpits sand, according to information from the administrators of the objects, was the tested material (included the NIH hygienic certificate with the entry "sand intended to be used in sandboxes and playgrounds"), purchased in the regional aggregates trading companies. According to the label description of the sand, it was a particulate material with a grain thickness of 0.2 to $2.0 \mathrm{~mm}$, having no loam particles. Organic matter content (determined by loss on ignition) and total nitrogen content (Kjeldahl method) [Ostrowska et al. 1991] were evaluated in the Regional Agrochemical Station in Szczecin on one average sample from each sandbox at the beginning of the playground season. Sand in terms of chemical parameters was not diversified, organic matter content ranged from $1.0-1.3 \mathrm{~g} \cdot \mathrm{kg}^{-1}$ and total nitrogen of $0.1-0.5 \mathrm{~g} \cdot \mathrm{kg}^{-1} .3$ sets of sandpits were chosen to be examined, and in each set there were fenced and unfenced sandpits in close proximity to one another - in order to eliminate the effect of different weather conditions and specificity of the location. Sandboxes in Szczecin were supplied in the sand by the administrator of the estate - Housing Association "Wspólny Dom" and sandpits in Gorzów by the Cooperative "Górczyn". The first set was contained of 2 sandpits, from which the sand was collected in 2012 and 2013 in spring and autumn. Both sandpits were located at Łucznicza Str. In the second case the sand was collected in 2012 and 2013 in spring and autumn from 3 sandpits located at Myśliwska Str. (fenced sandpit), Pasterska Str. (unfenced sandpit) and Czcibora Str. (fenced sandpit). In Gorzów Wielkopolski, 2 sandpits on Wróblewski's Str. (one fenced, located within the kindergarten area and the other one not fenced, located in close proximity to the kindergarten) and one unfenced on Pułaski's Str. were selected for the study (Table 1). The sand of these objects was collected in spring and autumn in 2013 and 2014. In all cases, the mate- 
rial samples were collected in spring, at the turn of April and May, after new sand was placed in sandboxes, and in September, at the end of the playing in sandpits season. From each sandbox, at each time, 9 samples of sand were collected. In each sandbox 3 areas of collecting the sand were typed (location is the centre and 2 opposite corner areas approx. $20 \mathrm{~cm}$ away from the edges of the sandbox), and each area 3 points of collecting (repetitions) by approx. $5 \mathrm{~cm}$ away from each other. The sand was taken from the surface layer at a depth of 1-10 cm and placed in containers of polypropylene. After being transported to the laboratory, the material was sieved through a $2 \mathrm{~mm}$ mesh to remove impurities, weight moisture content of the sand for each sample was determined and microbiological analyses were performed.

The microbiological analyses included:

- Quantification of live heterotrophic bacteria and fungi. Seeding of decimal dilutions of soil (sand) by submerged plate on the microbiological ground was performed. The norm PNEN ISO 6222: 2004 was used - the determination of the total number of colonies by inoculation on nutrient agar (methodology adapted to the requirements for soil bacteria through the use of medium described by Bunt and Rovira [1955] and adapted to the requirements for fungi by using Martin medium [1950].

- Detecting the presence of coliform bacteria. The methodology legislated in the Polish Norm PrPN-Z-19000-2 Soil quality was used - Assessment of Sanitary Condition of the Soil

- Detection and quantification of the presence of coliform bacteria.

- Detecting the presence of Salmonella bacteria. The methodology legislated in the Polish

Table 1. List and location of research objects

\begin{tabular}{|c|l|}
\hline \multicolumn{2}{|c|}{,Książąt Pomorskich” Housing Estate 1, Szczecin } \\
\hline 1. & Fenced sandpit at Łucznicza Street \\
2. & Unfenced sandpit at Łucznicza Street \\
\hline „Książąt Pomorskich” Housing Estate 2, Szczecin \\
\hline 1. & Fenced sandpit at Myśliwska Street \\
2. & Fenced sandpit at Czcibora Street \\
3. & Unfenced sandpit at Pasterska Street \\
\hline ,Górczyn” Housing Estate, Gorzów Wlkp. \\
\hline 1. & Fenced sandpit at Wróblewski's Street \\
2. & Unfenced sandpit at Wróblewski's Street \\
3. & Unfenced sandpit at Pułaski's Street \\
\hline
\end{tabular}

Norm PN-Z-19000-1:2001 Soil quality was used - Assessment of sanitary condition of the soil - Detection of the presence of Salmonella bacteria.

- Detecting the presence of intestinal parasites' eggs of Ascaris lumbricoides and Trichuris trichuria. The methodology legislated in the Polish Norm PN-Z-19000-4:2001 Soil quality was used - Assessment of sanitary condition of the soil - Detection of the presence of intestinal parasites' eggs of Ascaris lumbricoides and Trichuris trichuria.

In order to determine statistically significant differences in the number of bacteria and fungi between the objects and the terms of measurements, analysis of variance and Tukey's multiple comparison test, at the significance level $\alpha=0.05$ was performed. Before taking statistical analysis, the results were transformed using logarithmic function.

\section{RESULTS AND DISCUSSION}

The results of bacteria and fungi present in the sand taken from the sandpits are shown in Figures $1-3$. The test results clearly show that fenced playgrounds (including sandpits) significantly affect the number of microorganisms in the sand. In the case of unfenced sandpits, within a few months after the new sand was placed in the sandboxes, generally an increased growth of bacteria and fungi took place. Less intense growth of bacteria and fungi took place in the sand in fenced sandpits (Figure 1, 2, 3). In most fenced sandpits (compared in terms of number of microorganisms from unfenced sandpits), the sand contained a similar amount of bacteria and fungi in both seasons: spring and autumn. The sand taken from the unfenced sandpits at the end of the season usually contained several to several hundred percent more bacteria and fungi than in spring.

There are both fenced and unfenced playgrounds on the "Osiedle Książąt Pomorskich" in Szczecin on Łucznicza Street. The study selected two playgrounds located closest to each other, one fenced and one unfenced (Table 1). It can be indicated that the number of bacteria and fungi in the unfenced sandbox was much higher in autumn than in spring (usually by several dozen percent), and in the case of bacteria and fungi in the fenced sandbox fluctuations in numbers were 
much smaller, and even statistically insignificant (Figure 1). Only in 2012, the number of bacteria did not differ significantly in both terms of measurement, regardless of whether the sand was fenced or not (Figure 1).
A similar relation was found regarding the sand taken from two fenced sandpits and one unfenced, located on the Pomeranian Dukes Housing Estate in Szczecin. Fenced sandpits located at Myśliwska Str. and Czcibora Str. and unfenced

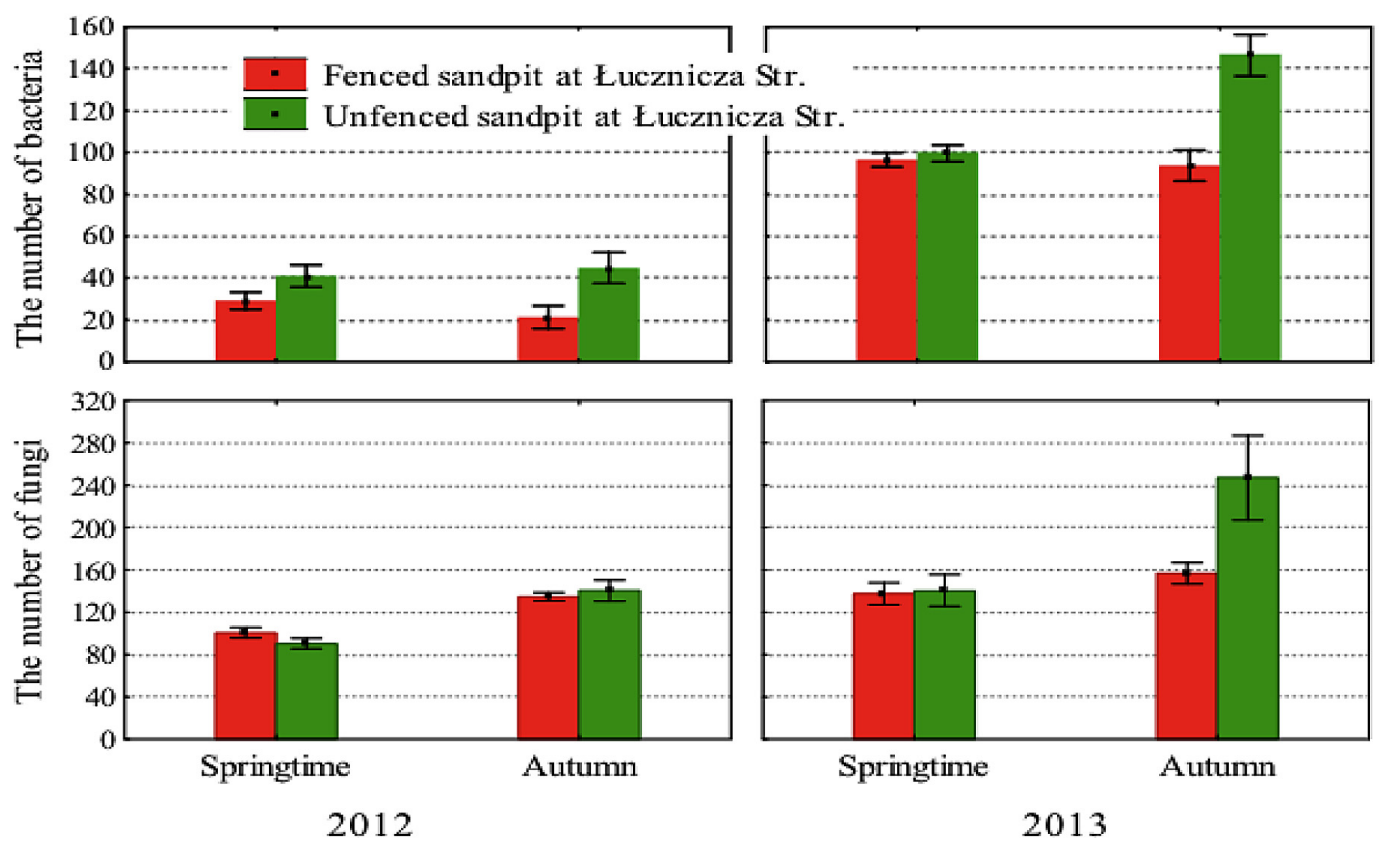

Figure 1. The number of bacteria $\left(\cdot 10^{4} \mathrm{CFU} \cdot \mathrm{g}^{-1}\right)$ and fungi $\left(\mathrm{CFU} \cdot \mathrm{g}^{-1}\right)$ in the sand taken from the sandpits located on the estate of the "Osiedle Książąt Pomorskich" in Szczecin, at Łucznicza Str.; the mean and standard deviation were included
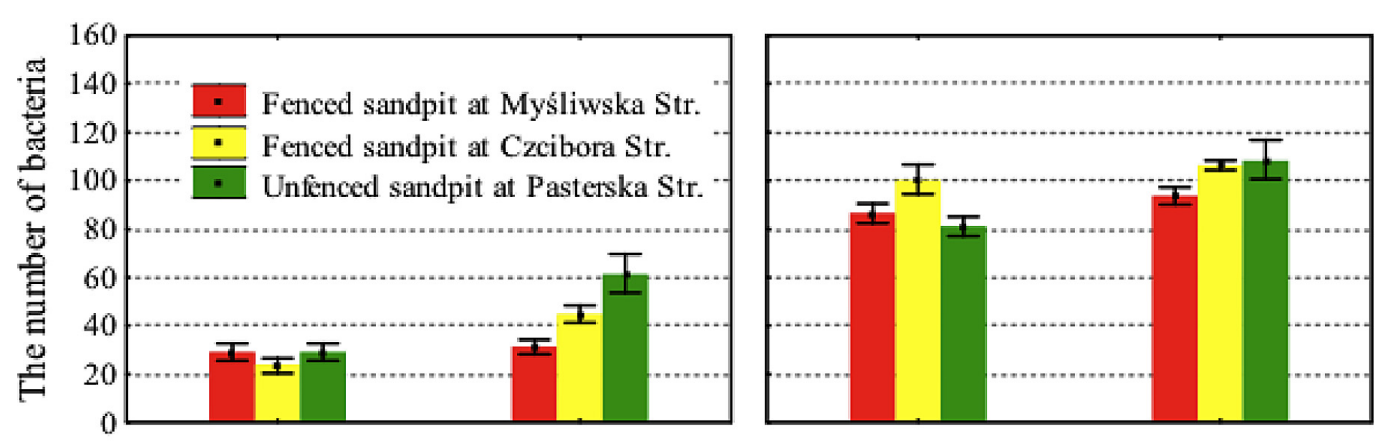

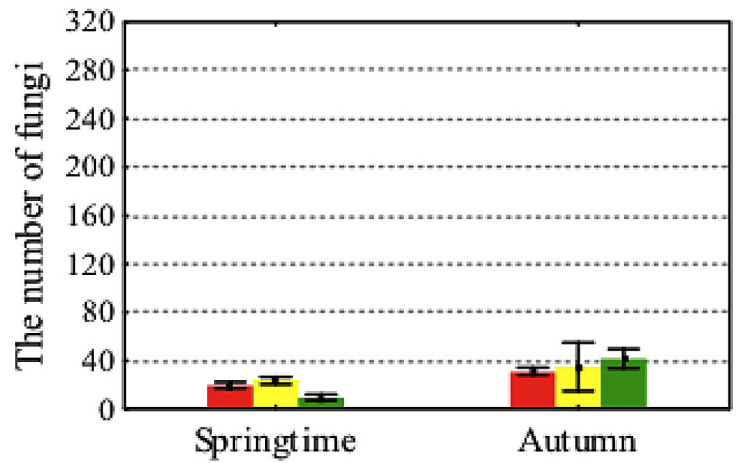

2012

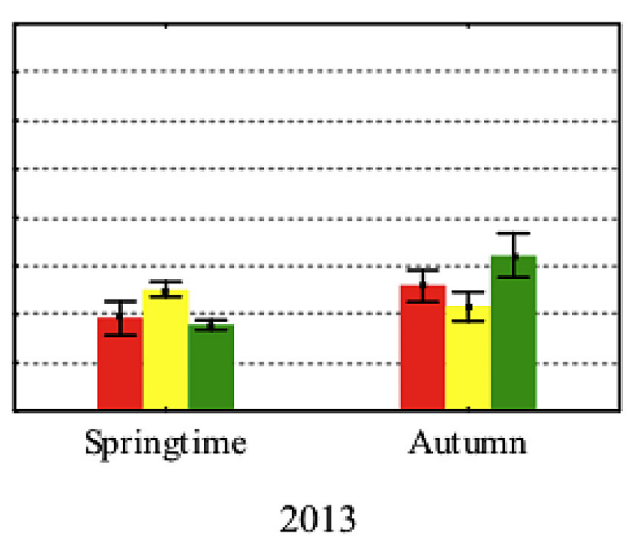

Figure 2. The number of bacteria $\left(\cdot 10^{4} \mathrm{CFU} \cdot \mathrm{g}^{-1}\right)$ and fungi $\left(\mathrm{CFU} \cdot \mathrm{g}^{-1}\right)$ in the sand taken from the sandpits located on the estate of the "Osiedle Książąt Pomorskich" in Szczecin, at Myśliwska, Czcibora, Pasterska Str.; the mean and standard deviation were included 
sandpit located at Pasterska Str. (Table 1). Sandpits are located a few tens of meters from each other. Overall, the number of bacteria and fungi in the sand from the unfenced sandpits always differed significantly in the spring and autumn season. In 2012, the differences were several hundred percent, and in 2013 tens of percent. In contrast, in each seasons - spring and autumn neither fenced sandpits show much differences in the number of bacteria and fungi, the differences were usually statistically insignificant (Figure 2).

The study included sandpits located in Gorzow Wielkopolski to compare and verify data obtained in Szczecin. The objects substantially differed in terms of use. They were frequently used sandpits, but in the case of the fenced one, located in the kindergarten area, protection against animals was very resultful; while the unfenced sandpit, located a few meters from the kindergarten was generally available for children and animals. Surprising results were obtained regarding the sand drawn from kindergarten's sandbox - there were twice as much bacteria and fungi than in the sand from unfenced sandpits located nearby (Figure 3).

The only confirmed thing was, similarly to the case of Szczecin's fenced sandpits, the small scope of changes in the number of bacteria and fungi between the ones at the beginning and at the end of the experiment. In the next measurement period - in autumn - the differences in the number of microorganisms equalized in the 3 objects. It was due to the increase in value of tested parameters in the sand from unfenced sandpits and / or reduced amount of bacteria and fungi in the sand from kindergarten's sandbox (Figure 3).

Indirectly, the lack of the development of microorganisms in the sand was caused by a barrier in a form of fence protecting from rubbish and plant debris blown into the sandpits by wind. The trash, after falling into a sandbox (mainly papers and packaging with food remnants were observed) was at the place until the human intervention, as the fencing did not allow them to fly out freely out of the sandbox recessed in the ground. The rubbish become a breeding ground for bacteria and fungi using organic substances from food remains and packaging, which is why their number increase steadily. In the fenced sandpits there were less rubbish, which does not mean that they were free from it, as children left food containers in the sand. In both fenced and unfenced sandboxes children themselves brought microorganisms, together with twigs, dirt on the soles of their shoes, and even urine. Therefore, even in the case of sand from the fenced sandpit, the usual increase in the number of microorganisms at the end of the usage season was reported. However, the change range was much smaller in

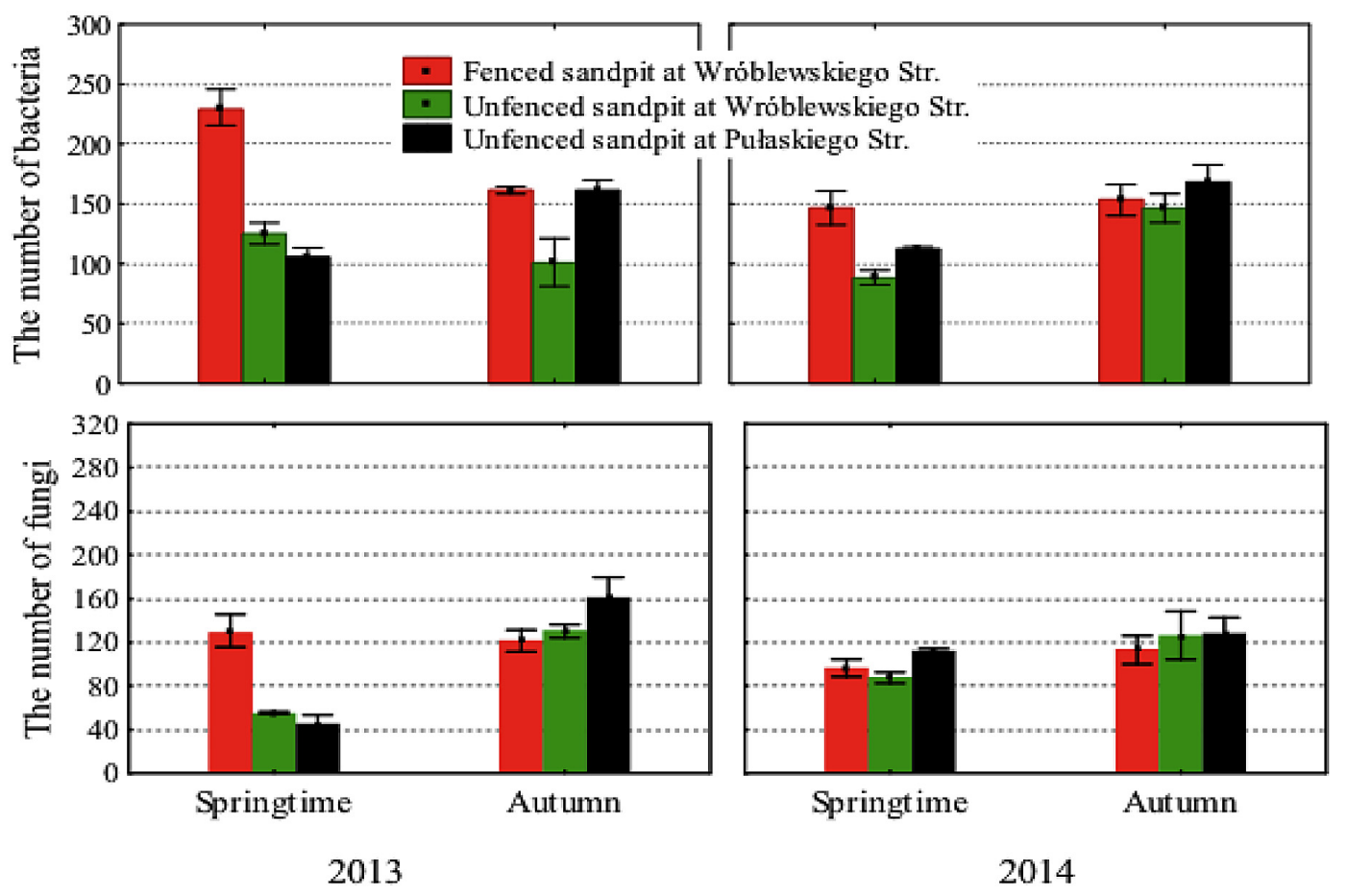

Figure 3. The number of bacteria $\left(\cdot 10^{4} \mathrm{CFU} \cdot \mathrm{g}^{-1}\right)$ and fungi $\left(\mathrm{CFU} \cdot \mathrm{g}^{-1}\right)$ in the sand taken from the sandpits located at "Górczyn" the estate in Gorzów Wlkp., at Wróblewski's and Pułaski's Str.; the mean and standard deviation were included 
the sand from fenced sandpits than in the case of unfenced ones. This observation demonstrates the main role of the fence as a barrier to rubbish, and consequently barriers to the development of microorganisms in the sand.

Soil, including loose sand, is a natural habitat for a huge pool of diverse groups of microorganisms, as in one gram of soil several billion of organisms can live [Paul and Clark 2000; Kunicki-Goldfinger 2008]. Sand contains little organic matter, so it is sparsely inhabited by organisms feeding on it (heterotrophic bacteria and fungi). Their number is significantly smaller than in the case of soils rich in organic sources of macronutrients [Błaszak 2013]. Therefore, it is not surprising nor a cause for concern that microorganisms were detected in the sand. Children should be exposed to environmental microorganisms to prepare their immune system to contact with a variety of antigens before reaching adulthood [Bird et al. 2008]. The mere presence of microorganisms in the sand is not disturbing, but a sharp increase in their numbers is. This fact suggests the presence of waste organic matter in the sandpits and the potential pathogens contamination of the sand.

The report of the 2012 concerning the maintaining cleanliness and order in public places by municipalities [NIK 2012] shows that more than a half of audited sandboxes did not have the required collateral in a form of a fence, and the vast majority of sandpits had no security from animals at night. Only in a few cases the replacement of sand more than once a year was reported in the municipalities covered by the audit. More detailed information on the existing sanitaryepidemiological threats in playgrounds refer to the information published by the State Sanitary Inspection [Tunkis 2009]. Nearly $10 \%$ of sandboxes (of 665 tested) were microbiologically contaminated and / or contained parasites. However, the frequency of deviation cases from the norm depended on the province. Lower Silesia, Łódź and Podlasie are the regions where the sanitary contamination was found in the sand from sandboxes the most often. In these cases the presence in the sand of coliforms was primarily identified, secondly Clostridium perfringens, Salmonella, and in several sandboxes the presence of intestinal parasites eggs.

In no object and no time limit the bacteria of Salmonella genus was detected in the sand nor was the presence of intestinal parasites eggs.
Therefore, the graphic image does not include the results of these analyses. When the sand (or other material) contacts with the faeces there are usually coliforms detected in the material (including the bacterium of the species Escherichia coli itself) [Żakowska and Stobińska 2000]. This is an obvious indicator of faecal contamination of environmental matrix but not necessarily with parasites (not all the animals and their faeces contain pathogenic microorganisms). Not all objects contaminated by faeces contain pathogens, but the probability of this fact is large [Żakowska and Stobińska 2000]. For example, $70 \%$ of the samples of sand taken from sandpits (107 tested objects in Sapporo, Japan) were contaminated with coliform bacteria. Only $10 \%$ of these samples also contained parasite eggs (usually Toxocara cati) [Matsuo and Nakashio 2005]. In some reports and publications related to biological contamination of sand, the proportion quoted above proportion of the presence of coliform bacteria, Salmonella bacteria and eggs of parasites have been repeated, i.e. approx. $70 \%$ of sandboxes contain coliform bacteria, including approx. $10 \%$ of the Salmonella bacteria and / or eggs of parasites [Dubna 2006; Tunkis 2009].

In every place demonstrated below the presence of coliform bacteria in the sand was stated and also often strains of Escherichia coli were detected (Table 2). Generally, the presence of these bacteria in the material indicates that the sand had contact with faeces. However, it should be noted that some genera of bacteria strains belonging to the coli group (Escherichia, Enterobacter, Citrobacter, Klebsiella) also exist and multiply in soil and a material rich in organic substance (some strains belonging to the genera Citrobacter and Klebsiella) [Sharma and Anad 2002; Drożdżyńska et al. 2012; Mahdi et al. 2014]. Consequently, strains of $E$. coli species are good indicators of sanitary condition contamination as they are able to grow only in warm-blooded organisms, surviving outside the body only a few to twelve months [Drewniak and Drewniak 2007].

Analysing the results of the sand examination which was carried out for two years on the Pomeranian Dukes Housing Estate in Szczecin, it was found that coliform bacteria, including Escherichia coli species were present in the sandpit sand in spring. This is quite surprising observation as sand was collected a few days after it was placed in sandboxes. Is it possible that in such a short time in all the examined objects the sand 
Table 2. The list of presence or absence of coliform bacteria and E. coli in the sand

\begin{tabular}{|c|c|c|c|c|c|}
\hline & \multirow{3}{*}{ The object's location } & \multicolumn{4}{|c|}{ Presence of coliform bacteria and $E$. coli } \\
\hline & & \multicolumn{2}{|c|}{2012} & \multicolumn{2}{|c|}{2013} \\
\hline & & Spring & Autumn & Spring & Autumn \\
\hline \multicolumn{6}{|c|}{ „Książąt Pomorskich” Housing Estate 1, Szczecin } \\
\hline 1. & Fenced sandpit at Łucznicza Street & ++ & +- & ++ & ++ \\
\hline 2. & Unfenced sandpit at Łucznicza Street & ++ & ++ & ++ & ++ \\
\hline \multicolumn{6}{|c|}{ „Książąt Pomorskich” Housing Estate 2, Szczecin } \\
\hline 1. & Fenced sandpit at Myśliwska Street & ++ & ++ & +- & ++ \\
\hline 2. & Fenced sandpit at Czcibora Street & ++ & +- & ++ & +- \\
\hline 3. & Unfenced sandpit at Pasterska Street & ++ & ++ & ++ & ++ \\
\hline \multicolumn{6}{|c|}{ „Górczyn” Housing Estate, Gorzów Wlkp. } \\
\hline 1. & Fenced sandpit at Wróblewski's Street & - & - & +- & ++ \\
\hline 2. & Unfenced sandpit at Wróblewski's Street & - & - & +- & ++ \\
\hline 3. & Unfenced sandpit at Pułaski’s Street & - & - & +- & ++ \\
\hline
\end{tabular}

Explanation: ++ presence of coliforms and E. coli; +- presence of coliforms and lack of $E$. coli detection.

contamination occurred? From the information obtained from Szczecin estate manager it is indicated that the sand placed in sandboxes in spring had hygienic approval (NIH), allowing it to be used by people. Therefore, it was decided to test the objects from another city. In Gorzów Wielkopolski there was an object exceptionally well protected from animals, located in the kindergarten area, and 2 objects not protected, located almost directly on the walking route selected for testing. In every object the presence of coliform bacteria was affirmed in spring, but not the bacteria belonging to the E. coli species. Moreover, it was found that the sand from kindergarten's sandbox, in addition to the presence of coliform bacteria (but not $E$. coli) was characterized by high values of bacteria and fungi (Figure 3 ). The presence of coliform bacteria and E. coli absence itself may indicate a former sand contamination. Over time, bacteria susceptible to environmental factors (e.g. E. coli) could be reduced. Sand from the kindergarten area differed visually from the sand from housing estate sandpits and was similar to the seaside sand. Studies have shown, however, that an attractive appearance does not always mean better sanitary quality. In Szczecin in spring both coliforms and E. coli were found in the sandboxes which clearly indicated a contamination of sand with faeces, while in the case of sandpits in Gorzow the presence of coliform bacteria was detected, but not the presence of $E$. coli. This indicates a lack of contact with the recent faecal contamination, otherwise $E$. coli the bacteria would have surely been present.
A possible answer to the surprising results on the sand from Szczecin sandpits could be the direct observation made in 2014 concerning a method of transporting the sand intended for residential sandpits. The workers were transporting the sand in the dump trucks dedicated to dispose garbage (the inscription on the car), it was visually noticed that precisely such a car dumped sand into one of Szczecin sandpits. On the same day the sand was studied - both coliforms and bacteria belonging to the $E$. coli species were found (the results of this study are not included in the table - it was carried out outside the research scheme). As a result of environmental interview, the information was obtained that in both cases of the estate in Szczecin and kindergarten in Gorzów, the contractors exporting old and providing new sand were trading aggregates. They were also engaged in the export of waste. Perhaps the transport of raw materials and waste had crossed, and consequently the contamination of sand at the stage of storage and transport took place. In addition, a separate issue was the lack of control concerning the quality of imported sand, as the recipient got sand in bulk, and the appearance did not indicate either the quality or the origin of sand. Within the second period of research - in autumn - in the sand from Gorzow sandpit the presence of coliform bacteria and Escherichia coli itself was found. Given the fact that the fences in kindergarten sandbox kept the dogs successfully away, the faecal bacterial contamination must have occurred by other means (e.g. the source could be cats, birds, rodents or children themselves). 
In several cases concerning fenced sandpits located in Szczecin, the opposite situation was observed. The coliforms and E. coli were present at the beginning, but in autumn the bacteria belonging to the $E$. coli species did not occur. Bacteria are not able to grow outside the body of the host, and after several months in water or soil they die. This observation can attest to the positive role of the fence as a barrier against dogs (to a lesser extent, cats and birds). However, not all fenced objects lacked the absence of $E$. coli in the sand collected in autumn. In those cases, the contamination of the sand could be a matter of chance. Similarly, Dubna et al. [2007] found that sand in sandboxes in Prague were contaminated regardless they were fenced or not. Although eggs of Toxocara spp were found more frequently in unfenced sandboxes, the fenced ones also contained numerous quantity of them.

Not only in Poland municipalities face the problem of maintaining cleanliness in public places. Interesting results were obtained by research scientists from Australia, analysing the spread of Salmonella enterica var. Java, which in 20072009 was the cause of hospitalization for many people in the environment strain. It was observed that the same serovar of the strain belonging to the Salmonella enterica species, which was isolated from patients, was also present in the sand taken from the recreational objects as well as from stool samples and swabs taken from rodents colonizing the surrounding areas, especially parks. These results lead to the conclusion that not only dogs and cats can be a source of contamination of sand, but also rodents, such as rats and mice commonly found in parks [Staff et al. 2009]. Also in the Netherlands there is a problem of maintaining sandpits in a state of purity. It is true that the most important risk factor for infection with salmonellosis remains through foods containing raw eggs and meat (the presence of different varieties of the $S$. enterica species were detected), but in second place, in terms of reported cases of infection, are sandboxes (with the predominant $S$. Typhimurium serovar) [ Doorduyn et al. 2006].

\section{CONCLUSIONS}

Fences around playgrounds constitute a barrier to garbage, and that contribute to maintaining the number of heterotrophic bacteria and fungi in the sand at a constant level throughout summer time when children play in the sandpits. However, in the sand from unfenced sandpits generally from spring to autumn, the number of bacteria and fungi had increased considerably. Fence do not always provide a barrier for impurities containing intestinal bacteria. The presence of Escherichia coli in the sand, after the season, both in fenced and unfenced sandboxes indicates the shortcomings of the playgrounds protection system against faecal bacteria. The source of these bacteria may be the children themselves or cats and rodents, as fences do not prevent them from entering the sandpits. No supervision of the transport of sand for sandboxes can also cause contamination of sand. Certified sand, probably free from coliform bacteria, can be contaminated upon contact with the surface of the dump track container, which probably the waste has already been transported. It concludes that fencing playgrounds does not entirely protect children against pathogens, but certainly reduces the potential contamination of sand. The most effective method to protect children against parasitic diseases remains practicing a habit of washing hands after playing and limiting the insertion of fingers into their mouth.

\section{REFERENCES}

1. Berliński D. 2009. Place zabaw - nadeszły zmiany. Ziel. Miej. 6(27), 46-47.

2. Błaszak M. 2013. Rozpowszechnienie w środowisku mikroorganizmów biodegradujących symazynę. Wyd. ZUT, Szczecin.

3. Borecka A. 2005. Nicienie z rodzaju Toxocaraniebezpieczne dla ludzi pasożyty odzwierzęce. KOSMOS. 54(1) 266, 105-108.

4. Bunt J.S., Rovira A.D. 1955. Microbiological studies of some subantarctic soil. Soil Sci. 6 (1), 119-128.

5. Doorduyn Y., Van Den Brandhof W., Van Duynhoven Y., Wannet W., Van Pelt W. 2006. Risk factors for Salmonella Enteritidis and Typhimurium (DT104 and non-DT104) infections in the Netherlands: predominant roles for raw eggs in Enteritidis and sandboxes in Typhimurium infections. Epidemiol Infect. 134, 617-626.

6. Drewniak E., Drewniak T. 2007. Mikrobiologia żywności. Wyd. WSiP Warszawa.

7. Drożdżyńska A., Pawlicka J., Czaczyk K. 2012. Charakterystyka i perspektywy wykorzystania Citrobacter spp. NIT. 3(6), 22-36.

8. Dubna S., Langrova I., Jankovska I., Vadlejch J., Peka S., Napravnik J., Fechtner J. 2007. Contami- 
nation of soil with Toxocara eggs in urban (Prague) and rural areas in the Czech Republic. Vet Parasitol. $144,81-86$.

9. Duszczyk E., Dziubek Z., Garlicki A. 2012. Choroby zakaźne i pasożytnicze. Wyd. PZWL Warszawa.

10. Gawor J., Borecka A., Dobosz S., Marczyńska M., Żarnowska-Prymek H., Trzebicka A., Juszko J. 2008. Życie Wet. 83(8), 655-658.

11. Gołdys A., Rogaczewska M., Szymborska M., Włoch R. 2012. Raport z badania jakościowego i ilościowego, dotyczącego potencjału rozwoju programów miękkich na infrastrukturze sportowej powstałej w ramach programu ,Moje Boisko - Orlik 2012”. Projekt Społeczny 2012 Wyd. Instytut Socjologii UW, Warszawa, https://www.orlik2012. pl/index.php/o-programie/historia-realizacji.

12. Kunicki-Goldfinger W. 2005. Życie bakterii. PWN Warszawa.

13. Lorenczewska M. 2015. Ubywa placów zabaw na toruńskich osiedlach. Dziennik Toruński, http://nowosci.com.pl/333346, Ubywa-placow-zabaw-natorunskich-osiedlach.html (18.05.2015).

14. Mahdi W.K.M., Ahmed H.A.B., Euoon S.M., Mohamed M.H. 2014. Extended Spectrum $\beta$-lactamase producing Klebsiella pneumoniae in Neonatal Units of Minya Governorate. Int. J. Curr. Microbiol. App. Sci. 3(12), 787-800.

15. Martin J.P., 1950. Use of acid, Rose Bengales and Streptomycin in the plate method for estimting soil fungi. Soil Sci. 69, 215-233.

16. Matsuo J., Nakashio S. 2005. Prevalence of fecal contamination in sandpits in public parks in Sapporo City, Japan. Vet Parasitol. 128(1-2), 115-119.

17. NIK. 2012. Informacja o wynikach kontroli realizacji zadań utrzymania przez gminy czystości i porządku w miejscach publicznych. $\mathrm{Nr}$ ewid. 121/2012/ P11/134/LKA, https://www.nik.gov.pl/ plik/id,4199,vp,5339.pdf

18. Ostrowska A., Gawliński S., Szczubiałka Z., 1991. Metody analizy i oceny właściwości gleb i roślin. Wyd. IOŚ, Warszawa

19. Paul E.A., Clark F.E. 2000. Mikrobiologia i biochemia gleb. Wyd. UMCS, Łódź.

20. Pisera K. 2011. Trójmiasto: Z placów zabaw znikają piaskownice. Dziennik Bałtycki, http://www.dziennikbaltycki.pl/artykul/391628,trojmiasto-z-placowzabaw-znikaja-piaskownice,id,t.html (18.05.2015).

21. Polska Norma PN-EN 1176 Wyposażenie placów zabaw i nawierzchnie.

22. Polska Norma PN-EN ISO 6222:2004 Określanie ogólnej liczby kolonii metodą posiewu na agarze odżywczym

23. Polska Norma PN-Z-19000-1:2001 Jakość gleby Ocena stanu sanitarnego gleby - Wykrywanie bak- terii z rodzaju Salmonella.

24. Polska Norma PN-Z-19000-4:2001 Jakość gleby - Ocena stanu sanitarnego gleby - Wykrywanie jaj pasożytów jelitowych Ascaris lumbricoides $i$ Trichuris trichiura.

25. Polska Norma PrPN-Z-19000-2 Jakość gleby - Ocena stanu sanitarnego gleby - Wykrywanie obecności i oznaczanie ilościowe bakterii z grupy coli.

26. Ptak W., Ptak M., Szczepanik M. 2008. Podstawy immunologii. Wyd. PZWL Warszawa.

27. Rozporządzenie Ministra Edukacji Narodowej i Sportu z dnia 31 grudnia 2002 r. w sprawie bezpieczeństwa i higieny w publicznych i niepublicznych szkołach i placówkach (Dz. U. 2003 nr 6 poz. 69 ze zm.).

28. Rozporządzenie Ministra Gospodarki z dnia 5 kwietnia 2011 r. w sprawie zasadniczych wymagań dla zabawek (Dz.U. $2011 \mathrm{nr} 83$ poz. 454 ze zm.).

29. Sharma M., Anad S.K. 2002. Biofilm evaluation as an essentials component of HACCP for food/ dairy processing industry - acase. Food Control. 13, 469-477.

30. Staff M., Musto J., Hogg G., Janssen M., Rose K. 2009. Salmonellosis Outbreak Traced to Playground Sand, Australia, 2007-2009. Emerg Infect Dis. 18(7), 1159-1162.

31. Tunkis K. 2019. Informacja z przeprowadzonego przez organy Państwowej Inspekcji Sanitarnej III etapu akcji pt.: „Piaskownice są dla dzieci”. Raport PIS (Państwowa Inspekcja Sanitarna).

32. Ubowska A., Łukaszewicz K. 2013. Koncepcja osiedlowego placu zabaw dla dzieci w wieku 3-6 lat spełniającego normy bezpieczeństwa. Prace Naukowe Akademii im. Jana Długosza w Częstochowie. 1, 421-432.

33. Ustawa z dnia 12 grudnia 2003 r. o ogólnym bezpieczeństwie produktów (Dz.U. 2003 nr 229 poz. 2275).

34. Ustawa z dnia 5 grudnia 2008 r. o zapobieganiu oraz zwalczaniu zakażeń i chorób zakaźnych u ludzi (Dz. U. 2008 nr 234 poz. 1570).

35. Ustawa z dnia 7 lipca 1994 r. Prawo budowlane (Dz. U. $2010 \mathrm{nr} 243$ poz. 1623 ze zm.).

36. Warchala M. 2010. Likwidować czy nie? Piaskownice nie są takie straszne. Wyborcza pl, http:// katowice.gazeta.pl/katowice/1,35019,8428321, Likwidowac_czy_nie_PiaskownPia_nie_sa takie_straszne.html (18.05.2015).

37. Yearley D., Berliński D. 2008. Bezpieczny plac zabaw - poradnik dla administratorów i właścicieli. Wyd. Urząd Ochrony Konkurencji i Konsumentów.

38. Żakowska Z., Stobińska H. 2000. Mikrobiologia i higiena $\mathrm{w}$ przemyśle spożywczym. Wyd. WPŁ Łódź. 